\title{
Structural constraints and determinants of economic growth in Cuba
}

\author{
Juan Carlos Palacios C.
} identify the main determinants and constraints that existed during a period when tighter restrictions on trade and financial activity forced the country to reorient its economic model and its position in the world economy. This analysis includes an exploration of the institutional dimension of the gross domestic product (GDP). The model, variables and methodology used for this purpose have all been adapted to the particular features and specificities of the Cuban economy. 


\section{I}

\section{Introduction}

The main objective of this analysis, which is by no means a finished piece of work, is to frame an academic discussion on the growth of the Cuban economy. The findings presented here should be viewed with a great deal of caution, since the problems that generally arise in this kind of quantitative analysis are compounded by the need to take the very specific aspects of an economy such as Cuba's into account. ${ }^{1}$

An analysis of Cuba's economic realities has served as the cornerstone for the hypothesis on which the study is based: that between 1986 and 2009, the growth of Cuba's production sector was subject to dual constraints stemming from both supply- and demand-side factors. On the one hand, an overly centralized regulatory framework may have suppressed economic efficiency, thereby reining in the expansion of output through supply-side factors. On the other, the shortage of foreign exchange that is typical of an open, developing economy may

$\square$ The author is especially grateful for the information, inputs and comments provided by the Cuban professors and researchers with whom he was fortunate enough to work and exchange views, as well as for the valuable suggestions and corrections furnished by an anonymous referee in the course of the preparation of this publication.

1 Some of the main difficulties were the presence of structural changes in the series and the lack of homogenous statistics or of a closer fit with some of the assumptions underlying the theoretical models. have curbed the country's economic growth through demand-side factors.

The stated objectives of this study are therefore limited to an analysis of the constraints and determinants influencing the country's economic growth. Due to space limitations, the discussion will leave aside a number of other variables that are fundamental for an understanding of the Cuban model, such as economic policy and social justice.

The article is structured as follows. Section II offers a brief overview of the literature on economic growth and the most important empirical studies of the Cuban economy that have been conducted to date. Section III models the Cuban production sector's GDP since 1986 and discusses factors that may have held back the Cuban economy's production potential and that should therefore figure in the explanation of why the GDP of this sector evolved as it did during this time period. Section IV describes the theoretical model underlying the specified production function, explains what data were used in measuring these variables and what corrections were made, builds a synthetic index for use in estimating how decentralized the economy is, and provides estimates, alternatively, of the sectoral and aggregate models that can be used to account for the growth trends seen in the Cuban production sector during the period in question. Section $\mathrm{V}$ presents the main findings of the study.

\section{II}

\section{Theoretical framework and empirical evidence}

Ever since the birth of economics as a scientific field of inquiry, the identification of the determinants of economic growth and of income differences across countries has been one of the recurring topics covered in the economic literature. In the 1930s, Harrod (1939) and, later, Domar (1946) extended the time horizon of analyses of the instability of capitalism to encompass a long-term perspective. Unlike the Keynesian approach, the exploration of growth trends within the framework of neoclassical models focused on supply-side factors such as technical progress and the available supply of factors of production.

During the 1970s, the need to incorporate countries' historical and cultural landscapes was recognized by proponents of the new institutional economics (NIE) school of thought. At the same time, Kaldor (1975 and 1976), Thirlwall (1979) and others were questioning the exogenous nature of factors of production, and the 
approach taken to explaining the dynamics of economic growth shifted to the demand side. Thirlwall was the first to formally describe the economy's dependence on the external sector when he expressed its growth as a function of exports, the terms of trade and the income elasticity of the demand for imports. ${ }^{2}$ The main idea behind this approach is that no country can grow more rapidly than its balance-of-payments equilibrium rate unless it can sustain deficits over a lengthy period of time.

In the decade that followed, Romer (1986), Lucas (1988), Rebelo (1991) and others framed what came to be known as the "endogenous growth theory". These authors took the neoclassical models and then reworked some of their basic assumptions, such as the exogeneity of technical progress or the constant returns to scale of the production function.

Growth was not viewed as a priority in the Cuban economic literature until the last few decades. Instead,

2 The simplest version of the balance-of-payments constrained growth (BPCG) model assumes constant prices and defines sustainable growth with a balance-of-payments equilibrium as the ratio between export growth and the income elassticity of the demand for imports. This came to be known as Thirlwall's Law. economic and social development was the pivotal focus of the political and academic agenda. Until the late 1980s, for example, González and others (1989) had not offered up an empirical analysis based on Cobb-Douglas production functions. In later studies, such as those of Mendoza (2003) or Torres (2007), this line of inquiry was pursued, and factors such as human capital and structural change were incorporated into the models. Doimeadios (2007) was the first to underscore the positive effect of a group of variables (proxies for structural change, openness to outside economies and the regulatory framework) on gains in total factor productivity (TFP) in Cuba. Her study is one of the main reference works used by researchers working on the subject now, since it represents the first and only time that a researcher has included the regulatory framework in a growth analysis of the Cuban economy. In other studies, such as those of Mendoza and Robert (2000), Cribeiro and Triana (2005), Vidal and Fundora (2008), and Fugarolas, Matesans and Mañalich (2008), Cuba's economic growth has been modelled on demand, with balance-of-payments constrained growth (BPCG) models being contrasted with foreign-exchange constraints on GDP.

\section{III}

\section{Modelling the Cuban production sector's GDP from 1986 onward}

The approach to modelling growth that has been taken in this study is based on a twofold theoretical tradition. On the one hand, it is based on the approach developed by Barro (1997), who advocated incorporating the institutional dimension into models of Cuban economic growth. ${ }^{3}$ On the other, it posits the centrality of external disequilibria as a determinant of a country's economic growth, which is also an assumption underlying BPCG models.

\section{The regulatory framework as a supply constraint}

The severity of the 1990s crisis forced the Cuban government to move quickly to launch a reform programme to liberalize and decentralize economic activities which, until then, had been centrally planned. It put an end to

\footnotetext{
3 The article referred to here is the study authored by Barro in 1997.
}

the government's monopoly on foreign trade, took steps to attract foreign direct investment (FDI), reorganized the agricultural sector by creating cooperatives and reopening free-trade markets, and authorized self-employment and the introduction of the enterprise optimization initiative in the civilian sector of the economy. The change in direction that began to be seen in the early 1990s was not pursued in the following decade, however, but was instead partially reversed with the creation of the general fund, the re-centralization of foreign trade, changes in the regulations on FDI, tighter restrictions on self-employment and the elimination of enterprise funds or the loss of financial autonomy associated with the new enterprise optimization regulations. Raúl Castro's assumption of power in early $2008 \mathrm{did}$, however, mark the beginning of changes in the economic model that culminated in the Sixth Congress of the Community Party of Cuba. 
The authors of studies that have applied growth accounting procedures to the Cuban economy (Mendoza, 2003; Doimeadios, 2007) are in agreement that what made the recovery of the 1990s possible was the upswing in TFP rather than increases in factors of production. This finding can be interpreted as a first sign of the possibility that a positive correlation exists between the economic decentralization measures introduced at that time and efficiency gains. Section IV.2 explains how a synthetic index was built for use in analysing this correlation by estimating the centralization-decentralization dynamic characterizing the Cuban production sector during the relevant period.

\section{Balance-of-payments equilibrium as a demand constraint}

A first sign that Cuba's economic growth might depend upon the performance of its external sector was provided by the observation that the periods during which the economy grew the fastest coincided with developments that promoted export growth (such as the country's entry into the Council for Mutual Economic Assistance (CMEA), the introduction of structural reforms in the external sector, or participation in recent integration schemes launched by the Bolivarian Alliance for the Peoples of Our America (ALBA)). The fact that the crisis of the early 1990s and the growth slump of recent years have been accompanied by serious foreign-exchange shortages constitutes yet another sign.

This relationship of dependence became especially evident when the Union of Soviet Socialist Republics (URSS) was dissolved, with Cuban exports plunging by $47 \%$, the supply of hard currency shrinking rapidly and imports falling so sharply that by 1993 their level stood at just 30\% of what it had been in 1989. The production sector's extremely heavy reliance on imported inputs brought production capacity to a virtual standstill.

Trends in GDP and external trade flows between 1975 and 2009, as shown in figure 1, also attest to the strong positive correlation between these variables. ${ }^{4}$

The recent history of this island country thus clearly points to the existence of an external constraint on long-term GDP growth.

4 The GDP correlation coefficient is 0.93 for the import series and 0.77 for the export series.

FIGURE 1

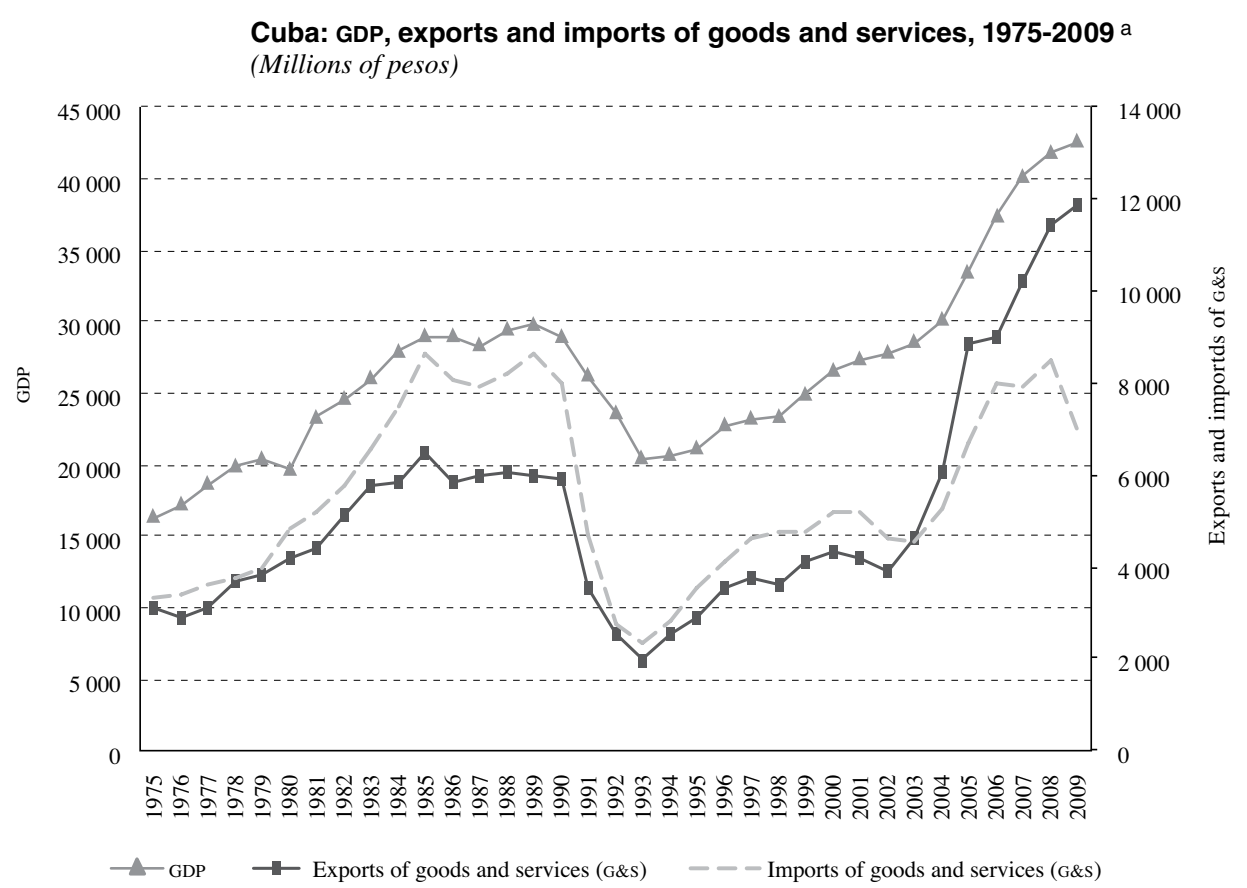

Source: prepared by the author on the basis of National Statistical Office, Anuario Estadístico de Cuba, Havana, various years, and data from the National Institute of Economic Research (INIE).

a Gross domestic product (GDP) at constant 1997 prices and exports and imports at current prices. 


\section{IV}

\section{The theoretical model}

\section{Empirical analysis}

One of the biggest issues to be resolved in any empirical analysis of production is the choice of which function to use in order to model it.

Although the Cobb-Douglas function is useful for representing the optimum position attainable by a steady-state economy, its underlying assumptions are somewhat implausible for economies that are having serious difficulties in financing their imports. In these cases, the constraints on a country's ability to import production inputs can be viewed as a bottleneck that limits production in the various sectors of the economy and prevents factors of production from being perfectly substitutable. Consequently, Cuba's GDP will be modelled here using a Leontief production function, in which GDP is determined in fixed proportions $\left(\alpha_{i}\right)$ by production factors $\left(X_{i}\right)$, regulatory changes $\left(R C_{n}\right)$ and a series of exogenous variables that are particularly influential in the case of Cuba $\left(Z_{k}\right)$.

$$
Y=F\left[\min \left\{\alpha_{i} X_{i}\right\}, R C_{n}, Z_{k}\right]
$$

According to Diewert (1971), the above production function can be generally formulated as:

$$
Y=\sum \sum \alpha_{i j}\left(X_{i} X_{j}\right)^{1 / 2}+\beta_{n} R C_{n}+\delta_{k} Z_{k}
$$

where: $\alpha_{i j}=\alpha_{j i}$

The generalized Leontief (GL) function offers a series of advantages over other types of functions, including linearity in parameters and the possibility of including null values in the model or of estimating the degree of substitutability existing among the relevant factors. Caves and Christensen (1980) demonstrate that the GL function has satisfactory local properties when the preferences are (or are nearly) homothetic and the elasticity of substitution is zero or near to zero, which makes this a more suitable type of function for modelling the growth of economies such as Cuba's.

\section{The data}

The series used to estimate the endogenous variable (GDP) and the exogenous variables (factors of production, regulatory changes and other external shocks) of the model will be described here. The data being used refer to production during the period 1986-2009.

$$
\text { GDP }(Y)
$$

The dependent variable corresponds to the series for GDP at constant prices for 1997 (National Statistical Office, various years).

In 2004, the National Statistical Office modified the methodology it had been using to measure GDP 5 because it had been underestimating the country's social accomplishments. These underestimates stemmed from the fact that the Cuban National Accounting System did not reflect either improvements in quality or the operating surpluses of non-commercial activities. In order to rectify this situation, in 2003 the method for calculating the value of services was switched to a price-based system. The budgetary units providing individual social services then began to bill the sectoral bureaus at the provincial level for these services, which are valued at the sum of the unit cost (plus a 25\% labour tax) and a profit ratio that is set by at the ministerial level (Jam, 2006).

The first results generated using the new methodology were published in the 2004 edition of the statistical yearbook Anuario Estadístico de Cuba, which also includes recalculations of GDP data for 2001-2003.

As shown in table A.1 of the annex, until 2006 this methodological change related only to the non-productive sector of the economy. In 2001-2003, the recalculations overvalued GDP in this sector of the economy by between $55 \%$ and 58\%. ${ }^{6}$ In 2007, the National Statistical Office modified the methodology again, and this change began

\footnotetext{
5 From the early 1990s until that time, Cuba had used the methodology outlined in the System of National Accounts of the United Nations. 6 Within the non-productive sector, the $80 \%$ increase in GDP registered between 2001 and 2003 for community, social and personal services was particularly striking.
} 
to have an impact on the GDP estimates of the production sector as well (with the exception of the agricultural and construction industries), as may be seen from the data appearing in table A.2 of the annex.

The lack of homogeneity in Cuba's official GDP series makes it an unsuitable basis for an econometric analysis, since the outliers in it would skew the estimates of the model's parameters. The following steps have been taken to reduce the bias and give the time series greater consistency:

(i) The scope of the study has been limited to the production sector so that a more homogeneous series can be constructed using the official data for a longer time period (1986-2006).

(ii) GDP values for production sectors for 2007-2009 have been corrected by applying, starting with 2006, the growth rates obtained using the new methodology to the GDP value of the preceding year, which reduced the sector's growth rate as of 2007 from $3.8 \%$ to $1.9 \%$.

The explanatory variables included in the model and the methodologies and data used to measure them are set out below.

- Factors of production:

\section{- Stock of physical capital (K)}

The national accounts of a planned economy such as Cuba's offer an advantage in that annual data, by sector, are published on fixed capital accumulation and stock. These figures are available up to 1989 (National Statistical Office, 1989). The rest of the series has been estimated by using the perpetual inventory methodology developed by Benhabib and Spiegel (1994).

$$
K_{i t}=K_{i 0}\left(1-\delta_{i}\right)^{t}+\sum_{q=1}^{t-1} I_{i t}\left(1-\delta_{i}\right)^{t-q}
$$

where $\delta_{i}$ is the linear depreciation rate for sector $i, I_{i t}$ represents the gross fixed capital formation (National Statistical Office, various years) of sector $i$ in year $t$, and $K_{i t}$ represents the capital stock of sector $i$ in year $t$.

The difficulty of estimating capital stock is further complicated, in the case of Cuba, by the repercussions that the disintegration of the socialist bloc in the late 1980s may have had on the depreciation assumptions. The collapse of the bloc put an end to the guaranteed supply of production inputs and machinery, and the technological obsolescence of the country's installed capacity as compared to that of capitalist economies became glaringly evident.

In this context, assuming a constant rate of depreciation in the capital stock accumulated by the sector during the period when the country was a member of CMEA (as was done in equation No. 3 ) is no longer reasonable. It is to be expected that the decline in economic value associated with the technological backwardness of the capital stock accumulated during the time that the socialist bloc held sway and the difficulty of maintaining it because of the lack of spare parts would increase over time. Equation No. 3 therefore needs to be adapted to the situation in the Cuban economy in 1990-2009 by assuming an increasing rate of depreciation for the capital stock accumulated up to 1989 and a constant one for the stock created through new investments. ${ }^{7}$

$$
\begin{aligned}
K_{i t}=\left[K_{i t-1}\right. & \left.-\sum_{q=1}^{t-2} I_{i t}\left(1-\delta_{i}\right)^{t-1-q}\right]\left(1-\alpha t \delta_{i}\right) \\
& +\sum_{q=1}^{t-1} I_{i t}\left(1-\delta_{i}\right)^{t-q}
\end{aligned}
$$

In equation No. 4 , the rate of depreciation of the capital stock accumulated during the time when Cuba was a member of CMEA rises linearly over time $\left(\mathrm{t}_{1989}=1\right)$ under the alternative assumptions of $\alpha=1$ and $\alpha=0.5$. Figure 2 shows the estimates for aggregate capital stock obtained using different depreciation assumptions for the stock amassed between 1986 and 1989.

The estimates arrived at using equation No. 4 reflect the capital losses sustained by the Cuban economy in the wake of the disintegration of the socialist bloc, which gave rise to one of its main structural problems (González, 1995).

\section{- Labour $(L)$}

Since Cuban workers' high level of education is one of the hallmarks of the country's socialist model, it is reasonable to include the quality of labour in the estimates. One of the most commonly used proxy variables for this purpose is years of schooling completed by members of the economically active population. Barro and Lee (1993) have used the perpetual inventory method to estimate this on the basis of the enrolment rates for the different academic cycles. Using that methodology, the average number of workers in each sector (National Statistical

7 Estimates for 1986-1989 are based on equation No. 3. 


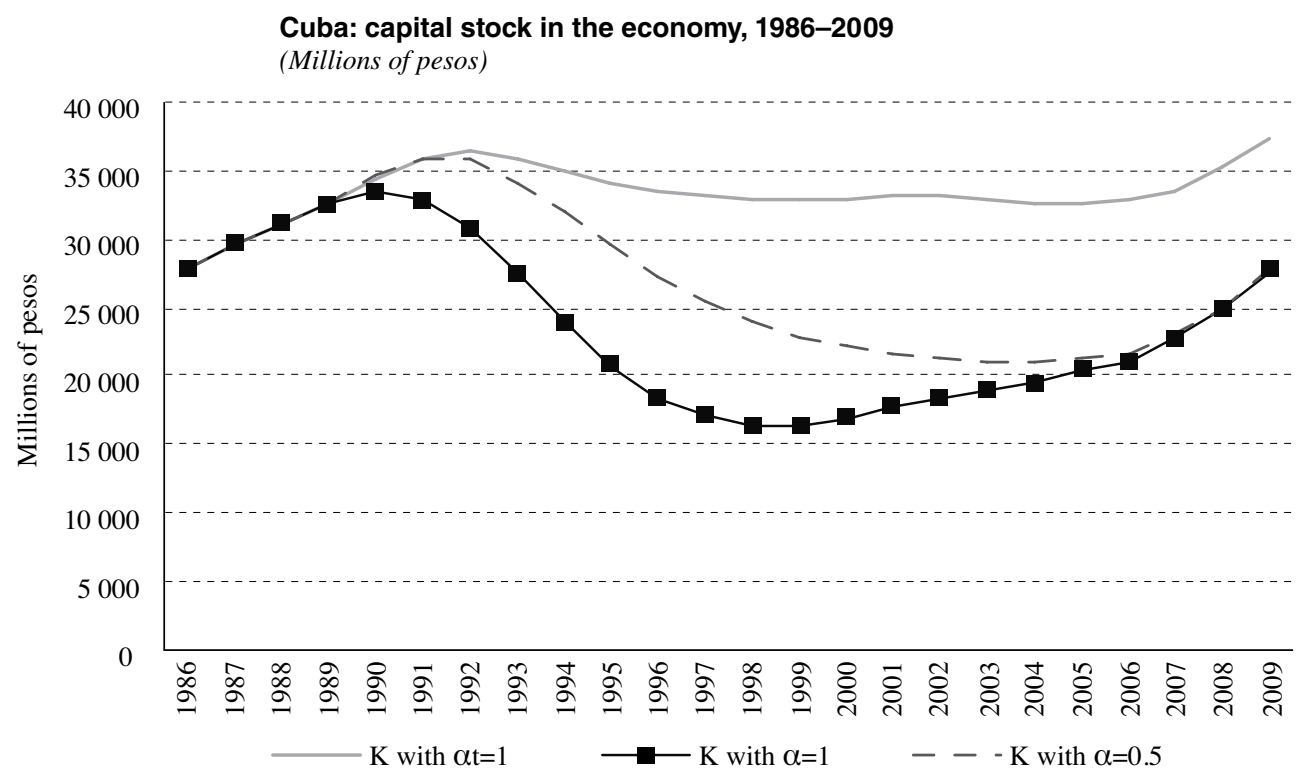

Source: prepared by the author on the basis of National Statistical Office, Anuario Estadístico de Cuba, Havana, various years.

Note: $\mathrm{K}$ with $\alpha \mathrm{t}=1$ refers to the estimated capital stock based on the assumption that the rate of depreciation is constant over time; $\mathrm{K}$ with $\alpha=1$ refers to the estimated capital stock based on the assumption that the rate of depreciation increases linearly at a gradient equal to 1 ; and $\mathrm{K}$ with $\alpha=0.5$ refers to the estimated capital stock based on the assumption that the rate of depreciation increases linearly at a gradient equal to 0.5 .

Office, various years; ECLAC, 2000) is multiplied by the average number of years of schooling for each year ${ }^{8}$ as calculated by Mendoza (2003) and the growth rates implicit in the computations of Barro and Lee (2010).

Here again, consideration must be given to the repercussions that the changes of the 1990s may have had in terms of the actual extent to which workers' educations have been put to use. When self-employment began to be allowed, the economy's entire incentive structure was altered, as many skilled workers switched over to activities that have a low level of value added but in which there is a greater link between income and the amount of work actually done. Given these circumstances, a second correction should be made in our measurement of labour in order to capture the underutilization of skilled workers who switched over to jobs requiring less education or training. Equation No. 5 therefore uses an alternative labour series in which self-employed workers are assumed to have the equivalent of an elementaryschool education (six years of schooling):

8 These data are not disaggregated by sector, so the average figure is assumed to correspond to all the sectors considered.

$$
L_{i t}^{c o}=\left(L_{i t}-T C P_{t} \times \alpha_{i}\right) Y S_{t}+T S E_{t} \times \alpha_{i} \times 6
$$

where $L_{i t}^{c o}$ indicates the average number of workers in sector $i$ in year $t$, corrected for years of schooling, $L_{i t}$ indicates the average number of workers in sector $i$ in year $t, T S E_{t}$ the number of self-employed workers in year $t, Y S_{t}$ the average number of years of schooling in year $t$, and $\alpha_{i}$ the percentage of self-employed workers in sector $i{ }^{9}$

\section{- Imports of production inputs (M)}

As explained in section III.2, the importation of inputs has represented a considerable constraint on production in Cuba. The parallel movement of the series shown in figure 1 suggests that this constraint has remained constant throughout the period under study. This means that a single regression will suffice, since

9 Using the data provided by Pérez-Izquierdo and others (2003) for 1998-2002, it is assumed that, during the period under review, $20 \%$ of self-employed workers were employed in the transport and communications sector and another $40 \%$ in commerce and tourism, since there is no indication that there has been any significant change in the structure of self-employment in Cuba. 
there is no need to identify a predominant constraint at each stage. Taking imported inputs into consideration as a third factor of production also makes it possible to arrive at a more accurate estimate of the constraints associated with the external sector in the Cuban economy. This is because the supply of foreign exchange in the different branches of activity has not only been influenced by trends in those activities' exports but has also been strongly affected by administrative decisions and centralized management mechanisms. Given the absence of sectorally disaggregated information, this estimate is based on the Standard Foreign Trade Classification used in Cuba's statistical yearbooks, which groups imports of the main inputs (at current prices) by sector. The series used for these estimates cover more than one fourth of total imports of goods and services.

In order to assess the quality of the proxy variable, its trend at an aggregate level has been compared with the trend in imports of goods and services during the period under review (see figure 3 ).

FIGURE 3
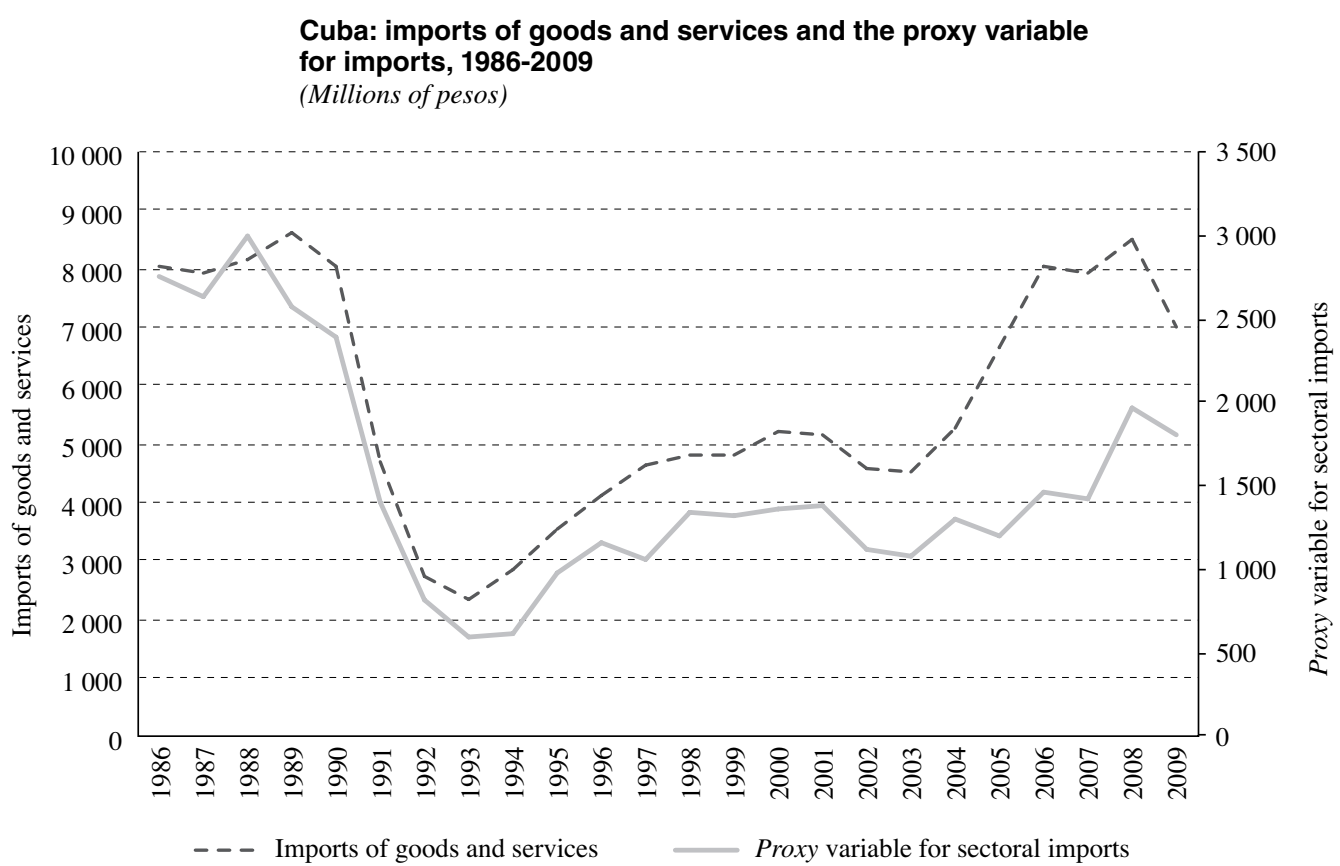

Source: prepared by the author on the basis of National Statistical Office, Anuario Estadístico de Cuba, Havana, various years.

The results show that there is a greater than $85 \%$ correlation between the two, which confirms the validity of using this proxy in estimating the different production sectors' imports of inputs.

- Regulatory changes

The selection and measurement of proxy variables for regulatory changes are of vital importance, given how damaging it would be to include variables that lack significance or that have been inaccurately measured. These variables have been chosen based on their relevance to the different sectors' economic growth and the availability of statistical data.

The variables chosen to represent regulatory reforms in the analysis are the following:

\section{— Openness to foreign direct investment (FDI)}

With the collapse of the socialist bloc, the steep drop in the Cuban economy's hard-currency financing capacity obliged it to relax its policy on FDI and to look to foreign capital for a way to mitigate its loss of capital stock. Over 15 years since the passage of FDI Act No. 77, it is clear that the three main objectives of that law have been achieved: fresh capital has flowed into the economy, technology transfer is taking place and the Cuban economy has gained access to new markets (Pérez, 2006). Because the level of FDI in all the different sectors is unknown, the number of international economic ventures is used as a proxy for each production sector's openness to FDI (ECLAC, 2000; Pérez, 2006, 2008 and 
2010; Cuba: Inversiones y Negocios, several issues; and Cuba Foreign Trade, several issues).

\section{- Degree of implementation of the Enterprise Optimization Programme (EOP)}

In 1998 the Enterprise Optimization Programme was launched throughout the civil sector of the economy. This programme focuses on introducing a more decentralized and flexible approach to the organization of work, production, the wage system and businesses' financial and investment policies with a view to achieving efficiency gains. This variable is estimated on the basis of the number of businesses participating in the programme in each sector (Marquetti, 2006; Caminos. Revista Cubana de Pensamiento Socioteológico, 2010).

\section{- Linkages with sectors that generate foreign exchange $(F X)$}

The first business schemes aimed at promoting foreign-exchange self-financing date back to late 1991, when the Financiera para el Turismo S.A. (FINATUR) was founded for the purpose of providing soft loans for the tourism sector. Thanks to this initiative, the country's share in the supply of goods and services to the tourism sector jumped from $12 \%$ in the mid-1990s to $67 \%$ in 2005 (Pérez, 2006). The participating companies had more scope for flexibility and financial autonomy than companies in the traditional sector, which relied on government allocations for their foreign exchange. This variable has been estimated on the basis of the flow of each sector's annual sales to the tourism sector and to the foreign-exchange stores (Tiendas de Recuperación de Divisas (TRD)), expressed in thousands of pesos at current prices. The data were provided by the Tourism Department of the National Institute of Economic Research (INIE).

\section{— Expansion of non-State forms of ownership (OWN)}

In 1993, with the adoption of Decree-Law No. 142, what were known as Basic Cooperative Production Units were set up in order to bring campesinos closer to the land and to create new incentives (e.g., the ability to sell surpluses on the agricultural market or to share in the profits of cooperatives). In that same year, DecreeLaw No. 141/93, on self-employment, was approved as well. In an effort to boost productivity, thousands of underemployed workers in the State sector received authorization to move into the private sector. This variable has been estimated on the basis of the number of workers (expressed in thousands) employed in the
non-State sector. Under current regulations, non-State workers can be employed in the agricultural, transport and communications, and commerce and tourism sectors, and the proxy variable is therefore null for manufacturing and construction. In the agricultural sector, the series has been built by adding together the number of private farmers and cooperative workers (National Statistical Office, various years; Cuban Economic Studies Centre). For the transport and communications and the commerce and tourism sectors, the series have been built on the basis of the series for self-employed workers published by the National Statistical Office. The sectoral weightings are based on data provided by Pérez-Izquierdo and others (2003), as explained in the discussion on the correction introduced for labour as a factor of production.

\section{- Expansion of free markets (MAR)}

In September 1994, the government authorized the reopening of agricultural markets. The introduction of market mechanisms was designed to trigger two positive externalities: first, a production incentive, since output could be sold at higher prices than those set by the central government; and, second, the changeover from prices set by the government to prices determined by supply and demand was expected to contribute to the measurement of key economic variables, such as prices and profit ratios. This series has been estimated on the basis of sales in free markets, including free agricultural markets and the self-employment market in the transport and communications and the commerce and tourism sectors (National Statistical Office, various years). The sectoral weightings are once again based on data from Pérez-Izquierdo and others (2003) and were calculated in the same way as they were for labour.

\section{- Economic Decentralization Composite Indicator $(E D)^{10}$}

Although they do pose methodological difficulties, ${ }^{11}$ composite indices can synthesize a large volume of information and make it easier to interpret and

\footnotetext{
10 The preliminary results of efforts to construct synthetic indices at the sectoral level showed that this methodology was unsuitable for some branches of economic activity (such as manufacturing and construction), since the Kaiser-Meyer-Olkin (KMO) coefficient was below 0.5 . Consequently, a single synthetic index for the entire production sector was developed.

11 Including the results' sensitivity to weightings, to the aggregation criteria used, and to the choice to include or exclude variables from the statistical analysis.
} 
compare (across individuals and across time) complex, multidimensional phenomena.

Generally speaking, composite indicators are constructed with the help of the following equation:

$$
I C=\sum_{i=1}^{m} w_{i} X_{i n}
$$

where $X_{\text {in }}$ represents each of the standardized individual indicators $\mathrm{X}_{i}$, and $w_{i}$ the weight assigned to the variable $X_{i n}$.

The aim here is to obtain an overview of the regulatory environment in Cuba between 1986 and 2009 by looking at the way in which the extent of decentralization in the production sector has evolved. The main components method was used to arrive at these estimates. This method involves linear combinations of the original variables in which the combinations are placed in decreasing order based on the amount of variance that they account for.

In line with Freudenberg (2003), once the theoretical framework and the relevant variables have been defined, the next step is to standardize them ${ }^{12}$ and to proceed with a correlational analysis, since, if common factors exist, they will yield a higher inter-variable correlation. To contrast the results, use has been made of the correlations matrix, the Kaiser-Meyer-Olkin (KMO) measure of sampling adequacy and Barlett's test of sphericity. ${ }^{13}$ The results validate the use of the main components method to build the composite index, since $100 \%$ of the correlation coefficients exhibit an absolute value of over 0.5 , the KMO coefficient is over 0.6 and the probability associated with the chi-square statistic is less than 0.05 (see annex B). The next step is to determine the optimum number of factors for inclusion in the composite index. The Statistical Package for the Social Sciences (SPSS) has been used to select factors with a value greater than unity that individually account for more than $10 \%$ of the variance and that together account for more than $60 \%$. In this case, a single component explains more than $83 \%$ of the variance and thus suffices. The last step is to estimate the weightings for each variable. The values suggested by the spss package for the construction of

12 The standardized variables are derived from the following expression: $X_{i n}=\left(X_{i}-X_{n}\right) / s_{i}$, where $X_{n}$ is the sampling measure and $s_{i}$ represents the corresponding standard deviation.

13 The statistical analysis was conducted using version 20 of the Statistical Package for the Social Sciences (SPSs). the composite index are included in the scoring matrix (see table 4 in annex B). ${ }^{14}$

Figure 4 shows the trend in the economic decentralization index for Cuba's production sector from 1986 to 2009.

The changes in this index follow the same path as was described in section III.1, with the periods 19922003 and 2007-2009 appearing as stages during which the regulatory framework was being decentralized and the years 2004-2006 being a time during which the economy was partially re-centralized.

\section{- Other external shocks}

It is reasonable to think that Cuba's GDP was affected by other external shocks during the years from 1986 to 2009 that have caused it to diverge from its potential path. Given Cuba's geographical and economic characteristics, it is worthwhile to analyse the potential impact on growth of changes in its terms of trade (TOT) (National Statistical Office, various years) and of the moderate and severe hurricanes that have passed over the island (HUR) (National Statistical Office, various years; www.cubahurricanes.org/). ${ }^{15}$ This last variable has been built by weighting the number of hurricanes that have swept over Cuba during the period under review by the minimum wind velocity for each category of hurricane. ${ }^{16}$ While it may well be that hurricanes have had a greater impact on certain sectors, such as agriculture, tourism and commerce or construction, in view of the huge volume of resources that have to be marshalled in order to repair the damage done by hurricanes, the analysis has been directed towards their effect on the production sector as a whole.

As can be seen from figure 5, the terms of trade turned sharply downward after the demise of the socialist bloc and have remained fairly stable since then. The strong decrease seen in 2008, when both moderate and severe hurricanes (Gustav and Ike) hit the island, largely accounts for the financial difficulties experienced by the country in that year.

\footnotetext{
14 The fact that the weighting obtained for the proxy variable for enterprise optimization is lower may be due to the fact that, unlike other measures, the move towards re-centralization made in 2004 did not affect the number of enterprises participating in the optimization programme, but rather their degree of autonomy, which the series used for this purpose is not capable of capturing.

15 Based on the Saffir-Simpson scale.

$16150 \mathrm{~km} / \mathrm{h}$ for moderate hurricanes and $210 \mathrm{~km} / \mathrm{h}$ for severe hurricanes.
} 
FIGURE 4

Cuba: synthetic index of the decentralization of the production sector, 1986-2009

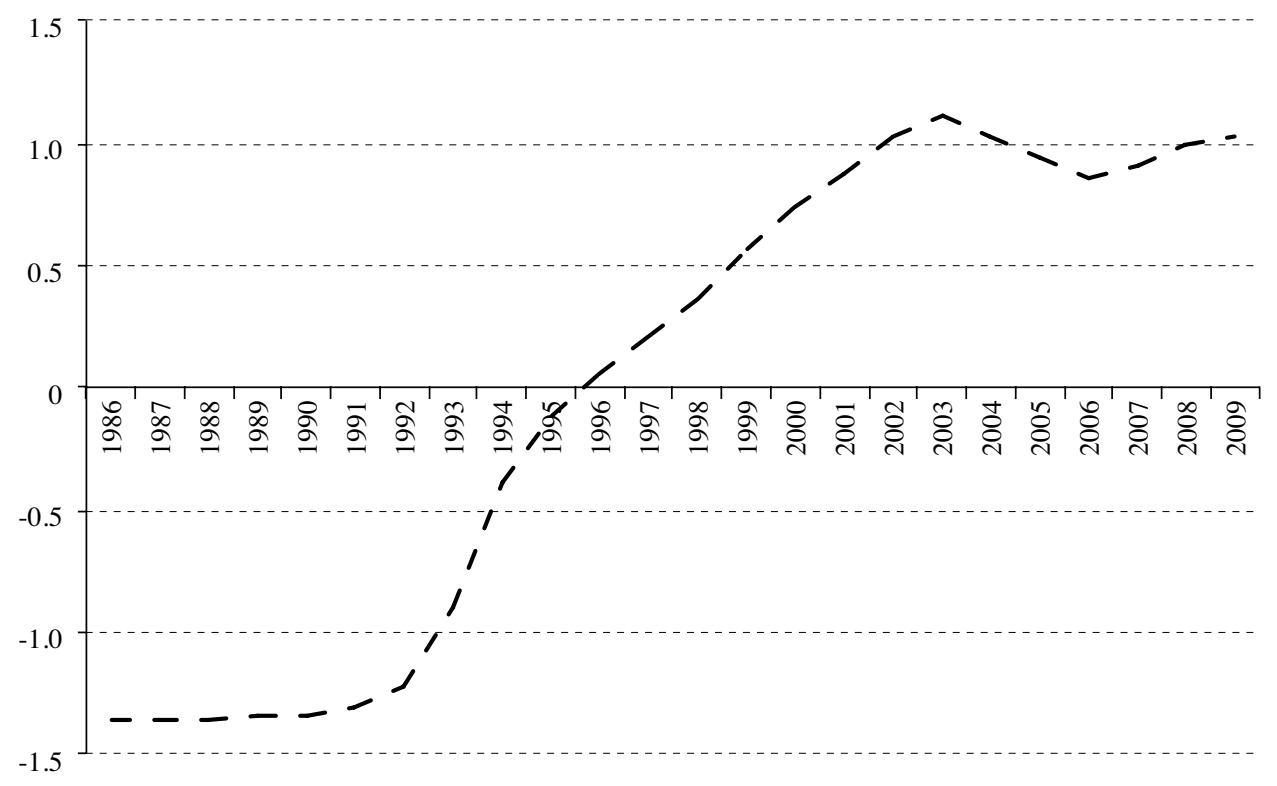

Source: prepared by the author.

FIGURE 5

Cuba: terms of trade $(1986=100)$ and number of hurricanes, weighted by their severity, 1986-2009

(Percentages)

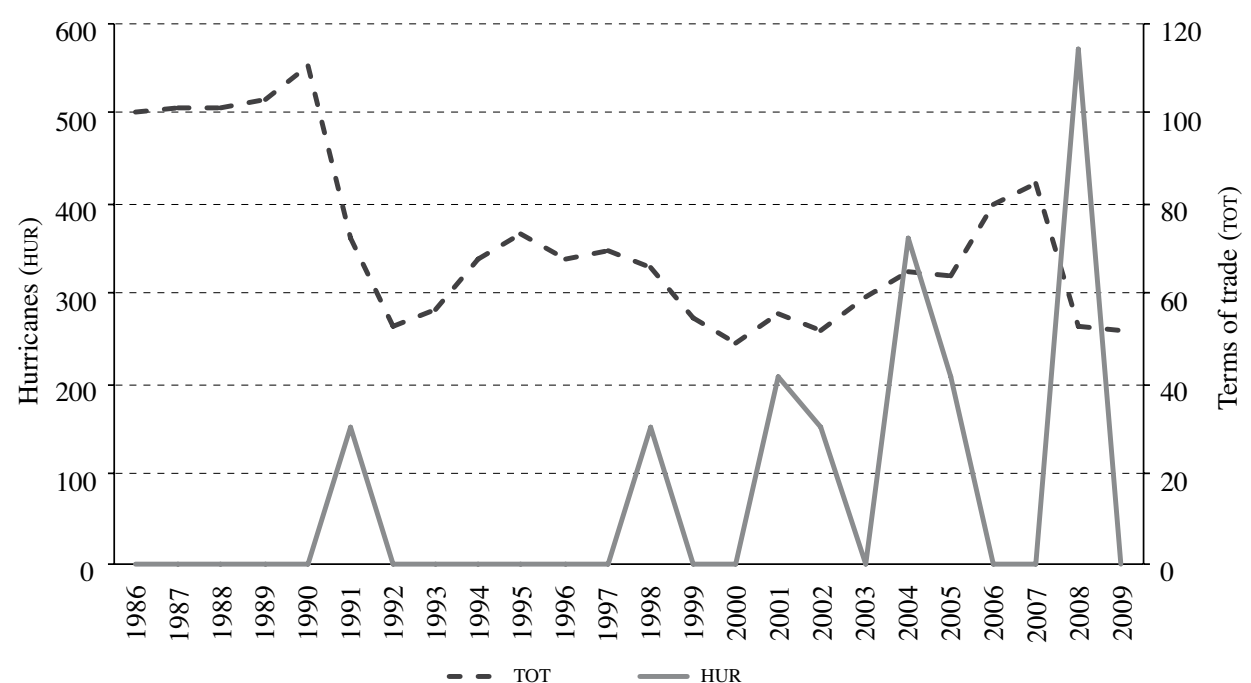

Source: prepared by the author on the basis of National Statistical Office, Anuario Estadístico de Cuba, Havana, various years, and www.cubahurricanes.org. 
Another external shock that has had a major impact on the Cuban economy's growth is the embargo imposed by the United States. The lack of annual statistics and the fact that the embargo has been in effect throughout the entire period covered by this study make it difficult to estimate the extent of its impact on any empirical basis.

As part of a preliminary analysis of the potential growth impact of these constraints, table 1 depicts the trend of sectoral data for each of the regulatory periods described in section III.1.

Although the crisis of the early 1990s was widespread, some sectors, such as agriculture and construction, experienced particularly harsh setbacks during those years. The trends in the variables used to estimate the impact of regulatory reforms reflect the same pattern of decentralization and re-centralization previously observed in the Cuban production sector during these years, as well as the piecemeal nature of those regulatory reforms.

The data do not provide a basis for determining the existence of any relationships of causality, although they do hint at some degree of correlation among growth, decentralization and trends in the external sector, which calls for a deeper analysis of these variables.

\section{Estimation methodology and results}

The specification of the model is based on the generalized Leontief function described in the discussion on equation No. 2. This includes the stock of physical capital, labour and imports of inputs as factors of production and proxy variables for major regulatory reforms and for exogenous factors that are of particular relevance for Cuba, such as trends in the terms of trade and the impact of moderate and severe hurricanes.

The empirical analysis is a two-stage process. The first step is to estimate a model for each of the economy's production sectors. This provides a basis for checking its validity at the sectoral level and comparing the effects of the different regulatory reforms on each of the various branches of activity. The next step is to estimate panel data for the production sector as a whole in order to bolster the estimates' reliability (Greene, 1997).

\section{(a) Sectoral analysis}

The limited degrees of freedom of the sectoral regressions imply a lower degree of consistency in the estimated parameters. Consequently, the explanatory variables will be restricted by the following expression:

$$
\begin{gathered}
Y_{t}=\alpha_{1} K_{t-1}+\alpha_{2} L_{t}+\alpha_{3} M_{t}+ \\
\alpha_{4} \sqrt{K_{t} L_{t}}+\alpha_{5} \sqrt{K_{t} M_{t}}+\alpha_{6} \sqrt{L_{t} M_{t}}+ \\
\alpha_{7} R C 1_{t-1}+\alpha_{8} R C 2_{t-1}+\alpha_{9} D_{i} H U R_{t}+e_{t}
\end{gathered}
$$

where $Y_{t}$ represents GDP in $t ; K_{t-1}$ the capital stock in $t-1 ; L_{t}$ the average number of workers in $t$; and $M_{t}$ the volume of imports in $t ; R C 1_{t-1}$ and $R C 2_{t-1}$ estimate the two most sweeping regulatory changes in each sector in $t-1 ; H U R_{t}$ represents the impact on GDP of the moderate and severe hurricanes in $t$, while $D_{i}$ is a dummy variable that takes a value of one (1) for the agricultural, tourism and construction sectors and a value of zero ( 0 ) for the rest. The introduction of both capital stock and the proxies for regulatory changes into the model are lagged. Given the problems posed by the endogeneity of capital stocks, which have been discussed extensively in the literature on growth, it is better to lag this variable and to use the lag as an instrumental variable for the existing capital stock. In the case of the regulatory variables, the lag is based on the idea that it will take at least a year before the effect of the changes on GDP will be felt.

Table 2 shows the results of the estimates arrived at by applying the ordinary least squares (OLS) method in equation No. 7 for each of the branches of activity making up the production sector. Given the small number of observations, in a second regression the variables that proved not to be significant in the first run were omitted.

The probability associated with the $\mathrm{F}$ and chi-square statistics reflects the inherent preferences in the model that have an impact on the aggregate model. The high value of $\mathrm{R}^{2}$ and the trend in estimated errors (see table E. 1 in the annex) appear to confirm the validity of the model at the sectoral level and to corroborate its strong explanatory power in terms of the growth of each of the economic activities making up the Cuban production sector. The introduction of measures to promote the decentralization of the economy, including those aimed at opening it up to FDI, appear to have driven the growth of production sectors in which this kind of investment has played an important role, such as manufacturing, communications and tourism. The steps taken to make enterprises more autonomous also appear to have been a significant driver of growth in the basic industrial and manufacturing sectors and in transport and communications. In the agricultural sector, the negative sign of the parameter linked to the development of non-State forms of ownership could be a reflection of the extremely poor production performance of the new cooperatives, which were heavily indebted 
Cuba: trend of sectoral variables, 1986-2009

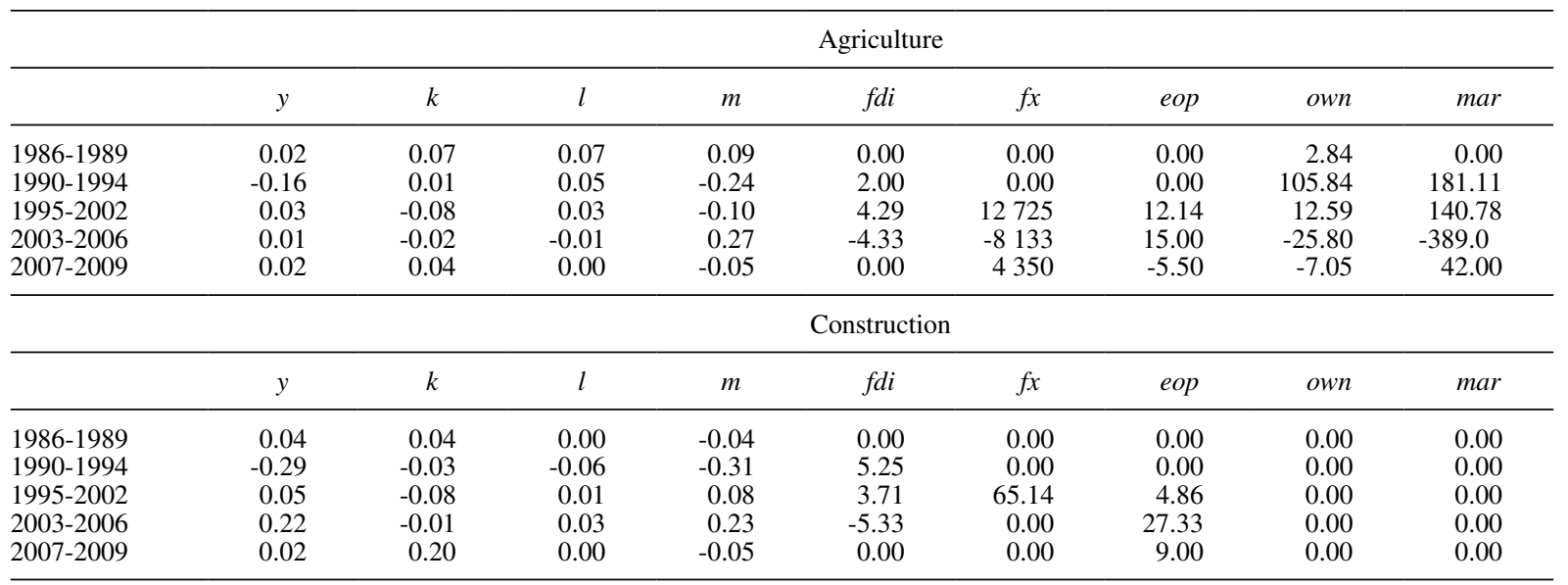

Basic industry a

\begin{tabular}{|c|c|c|c|c|c|c|c|c|c|}
\hline & $y$ & $k$ & $l$ & $m$ & $f d i$ & $f x$ & eop & $o w n$ & mar \\
\hline 1986-1989 & 0.06 & 0.07 & 0.17 & 0.07 & 0.00 & 0.00 & 0.00 & 0.00 & 0.00 \\
\hline 1990-1994 & -0.06 & -0.03 & 0.05 & -0.22 & 13.00 & 0.00 & 0.00 & 0.00 & 0.00 \\
\hline 1995-2002 & 0.06 & -0.03 & 0.00 & 0.09 & 3.29 & 1967 & 19.57 & 0.00 & 0.00 \\
\hline 2003-2006 & -0.01 & 0.03 & 0.04 & 0.00 & -1.67 & -600 & 8.00 & 0.00 & 0.00 \\
\hline 2007-2009 & 0.00 & 0.19 & 0.04 & 0.20 & 0.00 & 3800 & 1.00 & 0.00 & 0.00 \\
\hline
\end{tabular}

Manufacturing

\begin{tabular}{|c|c|c|c|c|c|c|c|c|c|}
\hline & $y$ & $k$ & $l$ & $m$ & $f d i$ & $f x$ & eop & own & mar \\
\hline 1986-1989 & 0.00 & 0.08 & 0.01 & -0.04 & 0.00 & 0.00 & 0.00 & 0.00 & 0.00 \\
\hline 1990-1994 & -0.08 & -0.01 & 0.03 & -0.43 & 10.75 & 0.00 & 0.00 & 0.00 & 0.00 \\
\hline $1995-2002$ & 0.02 & -0.05 & 0.02 & 0.02 & 0.86 & 59431 & 3.20 & 0.00 & 0.00 \\
\hline $2003-2006$ & 0.02 & -0.01 & -0.01 & 0.15 & -0.67 & -2974 & 16.40 & 0.00 & 0.00 \\
\hline $2007-2009$ & 0.02 & 0.05 & 0.02 & 0.06 & 0.00 & 44450 & 10.40 & 0.00 & 0.00 \\
\hline
\end{tabular}

Transport and communications

\begin{tabular}{|c|c|c|c|c|c|c|c|c|c|}
\hline & $y$ & $k$ & $l$ & $m$ & $f d i$ & $f x$ & eop & own & mar \\
\hline 1986-1989 & 0.02 & 0.02 & 0.02 & -0.08 & 0.00 & 0.00 & 0.00 & 0.00 & 0.00 \\
\hline 1990-1994 & -0.12 & -0.04 & -0.01 & -0.35 & 0.75 & 0.00 & 0.00 & 1.25 & 297.55 \\
\hline $1995-2002$ & 0.08 & -0.08 & -0.02 & -0.02 & 3.14 & 2775.6 & 2.29 & 1.42 & -60.78 \\
\hline $2003-2006$ & 0.07 & -0.01 & 0.03 & 0.17 & -1.33 & -4876 & 8.67 & 0.11 & -19.43 \\
\hline 2007-2009 & 0.05 & 0.04 & 0.02 & 0.14 & 0.00 & 3400 & 0.50 & 0.54 & 3.50 \\
\hline
\end{tabular}

Tourism and commerce

\begin{tabular}{rrrrrrrrrr}
\hline & $y$ & $k$ & $l$ & $m$ & $f d i$ & $f x$ & eop & own & mar \\
\hline $1986-1989$ & -0.03 & 0.03 & 0.06 & 0.02 & 0.33 & 0.00 & 0.00 & 0.00 & 0.00 \\
$1990-1994$ & -0.12 & -0.05 & 0.00 & -0.16 & 1.50 & 0.00 & 0.00 & 2.50 & 297.55 \\
$1995-2002$ & 0.04 & 0.15 & 0.05 & 0.21 & 2.71 & 0.00 & 1.00 & 0.85 & -60.78 \\
$2003-2006$ & 0.09 & 0.07 & 0.03 & 0.18 & 1.33 & 0.00 & 9.67 & 0.21 & -19.43 \\
$2007-2009$ & 0.01 & 0.08 & 0.02 & 0.01 & 0.50 & 0.00 & 6.00 & 1.08 & 3.50 \\
\hline
\end{tabular}

Source: prepared by the author.

Note: The variables $y, k, l$ and $m$ represent the average annual growth rates for the period in question.

The variables $f d i$, $f x$, eop, own and mar represent the average rates of increase in levels where null values appear in the series. The variable $f x$ is expressed in thousands of pesos.

a Includes mining and quarrying and electricity, gas and water. 
Estimates for each sector obtained using equation No. $7^{\text {a }}$

\begin{tabular}{|c|c|c|c|c|c|c|}
\hline $\begin{array}{l}\mathrm{Y}-\text { dep. variable } \\
\mathrm{N}=24\end{array}$ & Agriculture & Construction & Basic industry & Manufacturing & $\begin{array}{l}\text { Transport and } \\
\text { communications }\end{array}$ & $\begin{array}{c}\text { Tourism and } \\
\text { commerce }\end{array}$ \\
\hline L.K & ns & ns & $\begin{array}{c}0.092 \\
(0.005)\end{array}$ & ns & $\begin{array}{l}-1.139 \\
(0.001)\end{array}$ & ns \\
\hline $\mathrm{L}$ & $\begin{array}{c}0.705 \\
(0.000)\end{array}$ & $\begin{array}{l}-3.022 \\
(0.002)\end{array}$ & ns & $\begin{array}{c}0.594 \\
(0.000)\end{array}$ & $\begin{array}{l}-1.731 \\
(0.007)\end{array}$ & $\begin{array}{l}-4.791 \\
(0.000)\end{array}$ \\
\hline M & ns & ns & ns & $\begin{array}{c}0.012 \\
(0.108)\end{array}$ & $\begin{array}{c}0.001 \\
(0.020)\end{array}$ & ns \\
\hline $\mathrm{KL}$ & $\begin{array}{l}-0.636 \\
(0.000)\end{array}$ & $\begin{array}{c}1.211 \\
(0.002)\end{array}$ & $\begin{array}{l}-0.168 \\
(0.081)\end{array}$ & ns & $\begin{array}{c}3.853 \\
(0.000)\end{array}$ & $\begin{array}{c}7.610 \\
(0.000)\end{array}$ \\
\hline KM & $\begin{array}{c}0.137 \\
(0.000)\end{array}$ & ns & $\begin{array}{c}0.006 \\
(0.000)\end{array}$ & $\begin{array}{c}0.148 \\
(0.002)\end{array}$ & ns & $\begin{array}{l}-1.601 \\
(0.000)\end{array}$ \\
\hline LM & $\begin{array}{l}-0.083 \\
(0.000)\end{array}$ & $\begin{array}{c}1.029 \\
(0.003)\end{array}$ & ns & $\begin{array}{c}0.594 \\
(0.000)\end{array}$ & ns & $\begin{array}{c}1.607 \\
(0.000)\end{array}$ \\
\hline L.EOP & $\mathrm{ni}$ & ns & $\begin{array}{c}1.187 \\
(0.000)\end{array}$ & $\begin{array}{c}8.659 \\
(0.000)\end{array}$ & $\begin{array}{c}9.359 \\
(0.000)\end{array}$ & ns \\
\hline L.FDI & ni & ns & $\begin{array}{c}4.771 \\
(0.000)\end{array}$ & $\begin{array}{l}20.908 \\
(0.033)\end{array}$ & $\begin{array}{l}32.492 \\
(0.000)\end{array}$ & $\begin{array}{l}4.038 \\
(0.069)^{\mathrm{b}}\end{array}$ \\
\hline L.OWN & $\begin{array}{l}-1.810 \\
(0.015)\end{array}$ & ni & ni & ni & ni & $\begin{array}{r}-41.891 \\
(0.002)\end{array}$ \\
\hline L.MAR & ns & ni & ni & ni & ns & ni \\
\hline HUR & $\begin{array}{l}-94.41 \\
(0.037)\end{array}$ & ns & ni & ni & ni & ns \\
\hline $\mathrm{R}^{2}$ & 0.887 & 0.904 & 0.907 & 0.934 & 0.973 & 0.926 \\
\hline J-B prob. & 0.781 & 0.195 & 0.436 & 0.837 & 0.529 & 0.639 \\
\hline DW & 1.471 & 1.570 & 1.748 & 2.447 & 1.547 & 1.771 \\
\hline
\end{tabular}

Source: prepared by the author.

ni: Variable not included.

ns: Variable not significant in the first regression.

a $\mathcal{L}$ represents the lag operator; $\mathrm{K}$ represents capital, $\mathrm{L}$ labour, $\mathrm{M}$ imports of production inputs, KL the interaction between capital and labour, KM the interaction between capital and imports of production inputs, LM the interaction between labour and imports of production inputs, FX linkages with foreign-exchange-earning sectors, EOP the extent of enterprise optimization, FDI the extent of openness to foreign direct investment, owN the expansion of non-State forms of ownership, MAR the expansion of free markets, HUR the passage of moderate and severe hurricanes, J-B prob. the probability for the Jarque-Bera statistic, and DW the Durbin-Watson statistic.

b For the tourism sector, annual FDI flows are used as a proxy for openness to foreign direct investment (FDI) (data provided by the Department of Tourism of the National Institute of Economic Research (INIE)) because the parameter for that variable turned out to be negative in a preliminary regression.

and whose actual degree of autonomy was virtually nil (Nova, 2002). The growth performance of this sector also appears to have been hurt by the damage caused by hurricanes.

The use of a flexible production function, such as the generalized Leontief (GL) function, makes it possible to discern the complementarities existing among the different factors of production in most sectors of the economy. It comes as no surprise that the agricultural sector is the only one in which labour serves as a substitute for the other two factors, since this is the sector in which producers were most active in substituting labour for capital in the early 1990s in an effort to counter their strong reliance on imported inputs.

\section{(b) Aggregate analysis}

In the aggregate specification, all the regulatory proxies discussed in section IV.2 are added to the factors of production, as well as the occurrence of major hurricanes and trends in the terms of trade. 


$$
\begin{gathered}
Y_{i t}=\beta_{1} K_{i t-1}+\beta_{2} L_{i t}+\beta_{3} M_{i t}+ \\
\beta_{4} \sqrt{K_{i t} L_{i t}}+\beta_{5} \sqrt{K_{i t} M_{i t}}+\beta_{6} \sqrt{L_{i t} M_{i t}}+ \\
\beta_{7} F D I_{i t-1}+\beta_{8} E O P_{i t-1}+\beta_{9} F X_{i t-1}+ \\
\beta_{10} O W N_{i t-1}+\beta_{11} M A R_{i t-1}+\beta_{12} T T_{i t-1}+ \\
\beta_{13} H U R_{i t-1}+e_{i t}
\end{gathered}
$$

Equation No. 8 yields an estimate for a balanced six-sector panel, with observations from 1986 to 2009 using panel data techniques. A second regression for the shorter period of 1994-2009 is then run in order to shed light on the impact of the disappearance of the socialist

\begin{tabular}{|c|c|c|c|c|c|c|}
\hline \multirow{2}{*}{$\begin{array}{l}\text { Period } \\
\mathrm{Y} \text { - dependent variable } \\
\mathrm{N}=24\end{array}$} & \multicolumn{3}{|c|}{ 1986-2009 } & \multicolumn{3}{|c|}{ 1994-2009 } \\
\hline & Fixed effects & Random effects & Robust error & Fixed effects & Random effects & Robust error \\
\hline \multirow[t]{2}{*}{ L.K } & 0.060 & -0.001 & -0.001 & -0.036 & -0.024 & -0.025 \\
\hline & $(0.483)$ & $(0.993)$ & $(0.993)$ & $(0.759)$ & $(0.778)$ & $(0.686)$ \\
\hline $\mathrm{L}$ & -0.333 & -0.281 & -0.318 & -0.311 & -0.054 & -0.054 \\
\hline \multirow[t]{2}{*}{ M } & 0.001 & 0.001 & 0.001 & 0.002 & -0.001 & 0.001 \\
\hline & $(0.279)$ & $(0.678)$ & $(0.673)$ & $(0.124)$ & $(0.877)$ & $(0.804)$ \\
\hline \multirow[t]{2}{*}{$\mathrm{KL}$} & 0.288 & 0.262 & 0.262 & 0.638 & 0.106 & 0.106 \\
\hline & $(0.077)$ & $(0.067)$ & $(0.202)$ & $(0.009)$ & $(0.505)$ & $(0.195)$ \\
\hline \multirow[t]{2}{*}{ KM } & -0.031 & -0.019 & -0.019 & -0.043 & -0.003 & -0.003 \\
\hline & $(0.009)$ & $(0.073)$ & $(0.029)$ & $(0.045)$ & $(0.842)$ & $(0.772)$ \\
\hline LM & 0.038 & 0.021 & 0.021 & 0.030 & 0.002 & 0.002 \\
\hline \multirow{2}{*}{ L.FDI } & 4.876 & 5.286 & 5.285 & 5.271 & -0.475 & -0.475 \\
\hline & $(0.007)$ & $(0.001)$ & $(0.056)$ & $(0.192)$ & $(0.819)$ & $(0.472)$ \\
\hline \multirow[t]{2}{*}{ L.EOP } & 0.433 & 0.202 & 0.202 & 1.896 & 0.007 & 0.007 \\
\hline & $(0.505)$ & $(0.770)$ & $(0.682)$ & $(0.043)$ & $(0.991)$ & $(0.987)$ \\
\hline \multirow[t]{2}{*}{ L.FX } & 0.001 & 0.001 & 0.001 & 0.001 & -0.001 & -0.001 \\
\hline & $(0.038)$ & $(0.539)$ & $(0.405)$ & $(0.322)$ & $(0.293)$ & $(0.054)$ \\
\hline \multirow[t]{2}{*}{ L.OWN } & 0.208 & -0.588 & -0.588 & 1.024 & -0.419 & -0.419 \\
\hline & $(0.826)$ & $(0.400)$ & $(0.498)$ & $(0.386)$ & $(0.597)$ & $(0.397)$ \\
\hline \multirow[t]{2}{*}{ L.MAR } & 0.489 & 0.761 & 0.761 & 0.390 & 0.087 & 0.087 \\
\hline & $(0.008)$ & $(0.000)$ & $(0.056)$ & $(0.085)$ & $(0.654)$ & $(0.186)$ \\
\hline \multirow[t]{2}{*}{ TOT } & 18.389 & 13.943 & 13.944 & 6.961 & 5.142 & 5.142 \\
\hline & $(0.000)$ & $(0.000)$ & $(0.001)$ & $(0.049)$ & $(0.147)$ & $(0.190)$ \\
\hline \multirow[t]{2}{*}{ HUR } & -0.062 & -0.196 & -0.196 & -0.205 & -0.217 & -0.217 \\
\hline & $(0.774)$ & $(0.395)$ & & & & $(0.170)$ \\
\hline L.Y & $(0.000)$ & $(0.000)$ & $(0.000)$ & $(0.000)$ & $(0.000)$ & $(0.000)$ \\
\hline \multirow[t]{2}{*}{ Constant } & -867.09 & -733.09 & -733.09 & -732.95 & -169.71 & -169.71 \\
\hline & $(0.001)$ & $(0.000)$ & (0.003) & (0.028) & $(0.448)$ & $(0.440)$ \\
\hline $\mathrm{R}^{2}$ & 0.903 & 0.889 & 0.889 & 0.936 & 0.920 & 0.920 \\
\hline $\mathrm{p}-\mathrm{F}(14.172)$ & 0.000 & & & $(0.000)$ & & \\
\hline $\mathrm{p}-\mathrm{Chi}^{2}(14)$ & & 0.000 & & & 0.000 & \\
\hline Hausman test & 28.75 & $(0.005)$ & & 18.26 & $(0.108)$ & \\
\hline
\end{tabular}
bloc. Table 3 gives the results for both regressions, with estimates for fixed effects, random effects and robust errors.

TABLE 3

Results for estimates prepared using equation No. 8 a

Source: prepared by the author.

Note: the $\mathrm{P}$ value is shown in parentheses.

a $\quad \mathcal{L}$. represents the lag operator; K represents capital; L labour; M imports of production inputs; KL the interaction between capital and labour; KM the interaction between capital and imports of production inputs; LM the interaction between labour and imports of production inputs; FX linkages with foreign-exchange-earning sectors; EOP the extent of enterprise optimization; FDI the extent of openness to foreign direct investment; owN the expansion of non-State forms of ownership; MAR the expansion of free markets; TOT the terms of trade; HUR the passage of moderate and severe hurricanes; $\mathrm{p}-\mathrm{F}$ the probability for the $\mathrm{F}$ statistics, and $\mathrm{p}-\mathrm{Chi}^{2}$ the probability for the chi-squared statistic. 
The Hausman test can be used to make the choice between the fixed-effects and random-effects models, and its results show that the fixed-effects model is preferable in both cases. The robustness of the fixed-effects estimates is heightened by their similarity to the results obtained when robust errors are included.

The aggregate analysis therefore confirms what the sectoral estimates had indicated about the importance of taking the regulatory framework into consideration when attempting to develop an explanation for the growth of Cuba's production sector. This follows from the $95 \%$ significance level with the expected sign obtained for some of the parameters relating to regulatory changes. The steps taken to open the economy up to FDI, to create greater linkages with foreign-exchange-earning sectors and to promote free markets subject to supply and demand appear to have had a positive effect on the growth of the Cuban production sector.

The aggregate results confirm what the sectoral analysis had indicated about the relationship among the different factors of production, which follows along much the same lines: the expansion of labour needs to be coupled with more investment or more imports. These results confirm this factor's complementarity and the wisdom of using flexible production functions such as the generalized Leontief function. The factors' complementarity is underscored by the significant negative effect of expanding the amount of labour used without also increasing capital or production inputs. This may seem counter-intuitive, but it starts to make more sense when considered within the context of the Cuban economy during the period being covered here. Given the high level of underemployment present in the economy during the recovery (as of the end of 2010, government statistics put it at $25 \%$ of the economically active population), it becomes easy to see how the opportunity cost of continuing to increase the number of persons employed in the production sector could exceed the new workers' marginal productivity. This, in turn, would dampen economic growth by increasing the State's wage bill and thereby reducing the amount of funding available for productive investments.

The second hypothesis, according to which the expansion of Cuba's GDP is constrained by the supply of foreign exchange, is strengthened by the statistically significant positive effect of the terms of trade and the significance of imports when they are combined with capital or labour inputs.

The stability of the results when the estimate is limited to 1994-2009 is noteworthy, since this demonstrates that the main findings for the more extensive time period also hold true for the recovery stage.

Finally, a test can be run to see how solid the estimates are based on an analysis of their sensitivity to changes in the variables' construction and the model's specification. To this end, new alternative estimates can be calculated using equation No. 8 (see table D.1 in the annex) by employing different capital depreciation assumptions for the period during which Cuba was a member of CMEA and substituting the synthetic index calculated in section IV.2 for the regulatory changes. ${ }^{17}$ These new results match up with the findings obtained from the preceding analysis and thus underscore the importance of taking factors and constraints specific to the Cuban economy into consideration when modelling its GDP.

17 This also increases the degrees of freedom of the estimate and reduces the possible colinearity of the explanatory variables.

\section{V}

\section{Conclusions and implications for economic policy}

In view of the difficulty of building an econometric model of countries' economic growth patterns, the specific features of the Cuban model and the fact that some of the statistical series are not entirely consistent, a very cautious approach should be taken to the interpretation of this study's results and to their use in arriving at forecasts or projections.
Cuba's recent history shows how close a relationship exists between the trade-offs of regulation versus deregulation and the supply of foreign exchange available in the economy at any given point in time. In the presence of major financial limitations such as those seen after 1986, the production sector's growth appears to have been subject to a twofold structural constraint. In terms 
of supply, the overly centralized regulatory framework appears to have lowered efficiency levels and curbed GDP growth. On the demand side, the shortage of foreign exchange appears to have weakened the country's import capacity and curtailed its potential growth rate.

This hypothesis points to two possible approaches for stimulating the Cuban production sector's growth: one revolves around greater decentralization of the regulatory framework, while the other would focus on industrial and commercial policies designed to boost the competitiveness of Cuban exports and improve the country's terms of trade. A number of these types of policies were included in the conclusions reached at the Sixth Congress of the Communist Party of Cuba, where it was decided that public-sector payrolls need to be cut, that forms of non-State ownership should be fully developed (by granting genuine autonomy, providing material and financial resources, and authorizing the use of such forms of ownership in the industrial sector), that State and business functions should be separated, that free markets should be expanded and that a closer link between labour and income should be forged. Other approaches that would boost production potential have not yet been fully explored, however, as attested to by the limited scope of self-employment, the absence of a strong policy drive to spur foreign investment, which continues to be barred from strategic sectors of the economy (such as the farm sector), and the maintenance of a wage policy that undercuts the competitiveness of semi-public enterprises' exports. 
ANNEX A

Effect of methodological changes on measurement of GDP

TABLE A.1

Cuba: official GDP data for 2001-2006 included in the 2003 and 2006 editions of the Annual Statistical Yearbook

(Millions of pesos) $^{\text {a }}$

\begin{tabular}{|c|c|c|c|c|c|c|c|}
\hline & $\begin{array}{l}\text { Statistical Yearbook } \\
\text { of Cuba }\end{array}$ & 2001 & 2002 & 2003 & 2004 & 2005 & 2006 \\
\hline Agriculture & \multirow{6}{*}{$2003^{\mathrm{b}}$ and $2006^{\mathrm{c}}$} & 1924.1 & 1875.7 & 1920.6 & 1924.6 & 1700.5 & 1597.7 \\
\hline Basic industry & & 990.2 & 1055.5 & 1082.3 & 1045 & 1035.8 & 1064.5 \\
\hline Manufacturing & & 4780.6 & 4787.8 & 4692.9 & 4809.3 & 4864.7 & 4956.9 \\
\hline Tourism and commerce & & 7633.3 & 7788.7 & 8175.1 & 8232.8 & 8627.3 & 10581.5 \\
\hline Transport and communications & & 2715.6 & 2716.6 & 2791 & 2925.9 & 3166.2 & 3458.6 \\
\hline Construction & & 1658.1 & 1618.7 & 1689.6 & 1858.4 & 2209.1 & 3042 \\
\hline Non-productive sector & 2003 & 7655.8 & 7843.2 & 8150.7 & $\cdots$ & $\cdots$ & $\ldots$ \\
\hline Non-productive sector & 2006 & 11745 & 12169.9 & 12877.9 & 14227.8 & 17564.3 & 19362.6 \\
\hline GDP (previous methodology) & 2003 & 27267.7 & 27686.2 & 28475.4 & $\cdots$ & $\cdots$ & $\cdots$ \\
\hline GDP (current methodology) & 2006 & 31446.9 & 32012.9 & 33202.6 & 35023.8 & 39167.9 & 44063.8 \\
\hline $\begin{array}{l}\text { GDP previous methodology / } \\
\text { GDP current methodology }\end{array}$ & 2003 y 2006 & 1.15 & 1.15 & 1.16 & $\cdots$ & $\cdots$ & $\cdots$ \\
\hline $\begin{array}{l}\text { Non-productive sector, previous } \\
\text { methodology / Non-productive } \\
\text { sector, current methodology }\end{array}$ & 2003 y 2006 & 1.55 & 1.55 & 1.58 & $\cdots$ & $\cdots$ & $\ldots$ \\
\hline
\end{tabular}

Source: prepared by the author on the basis of National Statistical Office, Anuario Estadístico de Cuba, Havana, various years.

a At constant 1997 prices.

b Data calculated using the previous methodology.

c Data calculated using the new methodology.

GDP: gross domestic product.

TABLE A. 2

Official GDP data for 2004-2009 provided in the Statistical Yearbook of Cuba for 2009 (Millions of pesos) $^{a}$

\begin{tabular}{|c|c|c|c|c|c|c|c|}
\hline & $\begin{array}{c}\text { Statistical Yearbook } \\
\text { of Cuba }\end{array}$ & 2004 & 2005 & 2006 & 2007 & 2008 & 2009 \\
\hline 1. Agriculture & \multirow{8}{*}{2009} & 1924.6 & 1700.5 & 1597.7 & 1885.9 & 1897.9 & 1962.7 \\
\hline 2. Basic industry & & 845.7 & 836.5 & 873.0 & 931.5 & 944.5 & 940.2 \\
\hline 3. Manufacturing & & 5199.1 & 5266.3 & 5511.7 & 6043.4 & 6358.9 & 6348.6 \\
\hline 4. Tourism and commerce & & 8215.4 & 8603.4 & 10554.7 & 10620.6 & 10530.5 & 10758.7 \\
\hline 5. Transport and communications & & 2999.3 & 3245.0 & 3541.9 & 3768.6 & 4019.0 & 4117.8 \\
\hline 6. Construction & & 1858.4 & 2209.1 & 3042.0 & 2780.0 & 2848.0 & 2864.4 \\
\hline 7. Non-productive sector & & 11787.4 & 14646.5 & 15791.2 & 17853.3 & 19091.1 & 19359.6 \\
\hline 8. GDP & & 32829.8 & 36507.3 & 40912.2 & 43883.3 & 45689.9 & 46352.0 \\
\hline
\end{tabular}

Source: prepared by the author on the basis of National Statistical Office, Anuario Estadístico de Cuba, Havana, various years.

a At constant 1997 prices.

GDP: gross domestic product. 
ANNEX B

Validation of the analysis based on the main components method

TABLE B. 1

\section{Correlations matrix}

\begin{tabular}{|c|c|c|c|c|c|}
\hline Variables & OWN & MAR & FDI & FX & EOP \\
\hline OWN & 1.000 & 0.948 & 0.931 & 0.846 & 0.677 \\
\hline MAR & 0.948 & 1.000 & 0.980 & 0.847 & 0.507 \\
\hline FDI & 0.931 & 0.980 & 1.000 & 0.863 & 0.505 \\
\hline FX & 0.846 & 0.847 & 0.863 & 1.000 & 0.772 \\
\hline EOP & 0.677 & 0.507 & 0.505 & 0.772 & 1.000 \\
\hline
\end{tabular}

Source: prepared by the author.

Note: OWN represents the expansion of non-State forms of ownership, MAR the expansion of free markets, FDI the extent of openness to foreign direct investment, FX linkages with foreign-exchange-earning sectors, and EOP the extent of enterprise optimization.

TABLE B.2

\section{Total explained variation}

\begin{tabular}{|c|c|c|c|c|c|c|}
\hline \multirow[b]{2}{*}{ Component } & \multicolumn{3}{|c|}{ Initial eigenvalues } & \multicolumn{3}{|c|}{ Sums of the squared saturations of the extraction } \\
\hline & Total & $\begin{array}{c}\text { Percentage } \\
\text { variance }\end{array}$ & $\begin{array}{l}\text { Cumulative } \\
\text { percentage }\end{array}$ & Total & $\begin{array}{c}\text { Percentage } \\
\text { variance }\end{array}$ & $\begin{array}{l}\text { Cumulative } \\
\text { percentage }\end{array}$ \\
\hline 1 & 4.184 & 83.671 & 83.671 & 4.184 & 83.671 & 83.671 \\
\hline 2 & 0.647 & 12.941 & 96.612 & & & \\
\hline 3 & 0.139 & 2.778 & 99.390 & & & \\
\hline 4 & 0.018 & 0.370 & 99.759 & & & \\
\hline 5 & 0.012 & 0.241 & 100.00 & & & \\
\hline
\end{tabular}

Source: prepared by the author.

TABLE B. 3

KMO and Barlett test

\begin{tabular}{llc}
\hline Kaiser-Meyer-Olkin (KMO) measure of sampling adequacy & 0.648 & \\
\hline Barlett's test of sphericity & Chi $^{2}$ & 192.47 \\
\cline { 2 - 3 } & P-value & 0.000 \\
\hline
\end{tabular}

Source: prepared by the author.

TABLE B. 4

Matrix of coefficients for the calculation of component scores

\begin{tabular}{lcccccc}
\hline Component & OWN & MAR & FDI & FX & EOP \\
\hline 1 & 0.232 & 0.227 & 0.227 & 0.226 & 0.176 \\
\hline
\end{tabular}

Source: prepared by the author.

Note: own represents the expansion of non-State forms of ownership, MAR the expansion of free markets, FDI the extent of openness to foreign direct investment, FX linkages with foreign-exchange-earning sectors, and EOP the extent of enterprise optimization. 
ANNEX C

Proxy variable for imports

TABLE C.1

\section{Imports of selected production inputs used in estimating the extent} of sectoral external constraints

Agriculture

Livestock fodder, fertilizers, herbicides, anti-germinants and plant-growth regulators, wheeled tractors, accessories and spare parts for agricultural equipment.

Basic industry

Chemicals and related products, non-metallic mineral manufactures, soil mixing and handling equipment, stone, ores and other solid mineral substances, metalworking machinery.

Manufacturing

Untanned hides and skins, textile fibres and wastes, spare parts for machinery used in the production of textiles, footwear, graphics, glass, food-processing, cork and wood, and industrial sewing machines.

Tourism and commerce

Furniture and parts thereof, bedding, mattresses, cushions and similar stuffed furnishings, other metal furniture.

Transport and communications

Transport machinery and equipment, power generators, internal combustion engines for airplanes, telecommunications devices and equipment, sound recording and reproduction equipment, roadway equipment, passenger transport equipment, mass transit equipment, merchandise transport equipment, road tractors for semi-trailers, motorcycles and parts and accessories thereof, trailers and semi-trailers, and other transport equipment.

Construction

Refractory cements, mortars, concretes and similar compositions, ceramic flags and paving, hearth or wall tiles, ceramic mosaic cubes, asbestos-cement and fibre-cement, equipment accessories and spare parts, construction equipment.

Source: prepared by the author on the basis of National Statistical Office, Anuario Estadístico de Cuba, Havana, various years. 
ANNEX D

\section{Aggregate estimate}

TABLE D. 1

Alternative estimates of Cuba's GDP, 1986-2009

(Based on different capital depreciation assumptions and a synthetic index of economic decentralization)

\begin{tabular}{|c|c|c|c|}
\hline $\begin{array}{l}\mathrm{Y} \text { - dependent variable } \\
\mathrm{N}=24\end{array}$ & $\begin{array}{l}\text { Assumption of increasing rate } \\
\text { of capital depreciation } \alpha=1\end{array}$ & $\begin{array}{l}\text { Assumption of constant rate of } \\
\text { capital depreciation }\end{array}$ & $\begin{array}{c}\text { Synthetic index of economic } \\
\text { decentralization }\end{array}$ \\
\hline$K(-I)$ & 0.055 & -0.082 & 0.132 \\
\hline $\mathrm{L}$ & $-0.337^{a}$ & $-0.399^{a}$ & $-0.088^{c}$ \\
\hline м & 0.001 & -0.001 & 0.001 \\
\hline KL & $0.286^{\mathrm{c}}$ & $0.469^{\mathrm{a}}$ & 0.021 \\
\hline KM & $-0.027^{b}$ & $-0.019^{c}$ & $-0.025^{b}$ \\
\hline LM & $0.027^{\mathrm{a}}$ & $0.026^{\mathrm{a}}$ & $0.032^{\mathrm{a}}$ \\
\hline L.FDI(-I) & $5.739^{\mathrm{a}}$ & $5.392^{\mathrm{a}}$ & --- \\
\hline L.EOP(-I ) & 0.056 & 1.419 & --- \\
\hline L.FX(-I) & $0.001^{\mathrm{c}}$ & -0.001 & --- \\
\hline L.oWN(-I) & 0.524 & 0.719 & --- \\
\hline L.MAR(-I) & $0.482^{\mathrm{a}}$ & $0.413^{b}$ & --- \\
\hline L.ED & $\ldots$ & $\ldots$ & $219.16^{\mathrm{a}}$ \\
\hline тот & $17.283^{\mathrm{a}}$ & $16.056^{\mathrm{a}}$ & $16.50^{\mathrm{a}}$ \\
\hline HUR & -0.079 & -0.099 & -0.189 \\
\hline L.Y (-I) & $0.813^{\mathrm{a}}$ & $0.842^{\mathrm{a}}$ & $0.829^{a}$ \\
\hline Constant & $-636.69^{a}$ & $-650.17^{b}$ & $-704.79^{a}$ \\
\hline $\mathrm{R}^{2}$ & 0.901 & 0.900 & 0.901 \\
\hline $\mathrm{P}-\left(\mathrm{F}, \mathrm{Chi}^{2}\right)$ & 0.000 & 0.000 & 0.000 \\
\hline Hausman test & 0.003 & 0.047 & 0.000 \\
\hline
\end{tabular}

Source: prepared by the author.

Note: The estimates for the three models were calculated using fixed effects in line with the results of the application of the Hausman test. $\mathcal{L}$ represents the lag operator; K represents capital; L labour; M imports of production inputs; KL the interaction between capital and labour; KM the interaction between capital and imports of production inputs; LM the interaction between labour and imports of production inputs; FX linkages with foreign-exchange-earning sectors; EOP the extent of enterprise optimization; FDI the extent of openness to foreign direct investment; ED the composite index for economic decentralization; OWN the expansion of non-State forms of ownership; MAR the expansion of free markets; TOT the terms of trade; HUR the passage of moderate and severe hurricanes; $\mathrm{p}-\mathrm{F}$ the probability of the $\mathrm{F}$ statistic, and $\mathrm{p}$-Chi ${ }^{2}$ the probability of the chi-squared statistic.

a Significant at a $99 \%$ confidence interval.

b Significant at a $95 \%$ confidence interval.

c Significant at a $90 \%$ confidence interval. 
ANNEX E

\section{Sectoral estimate}

FIGURE E.1

\section{Comparison of the real GDP of Cuban production sectors in 1986 and 2009 with estimates based on equation No. 7 a}

Agriculture

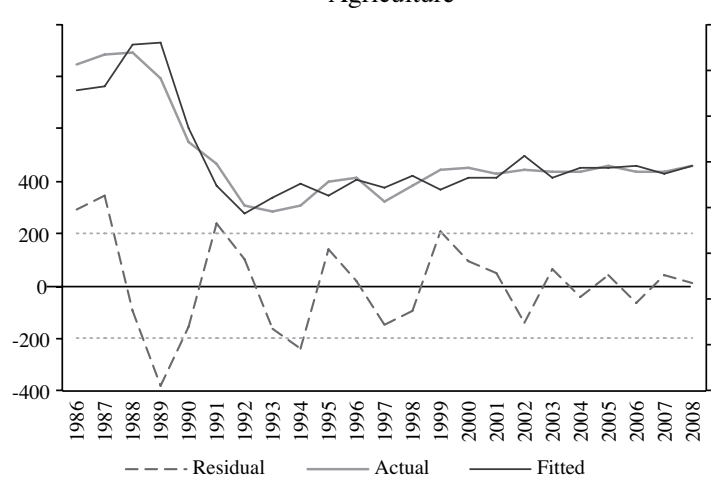

Construction

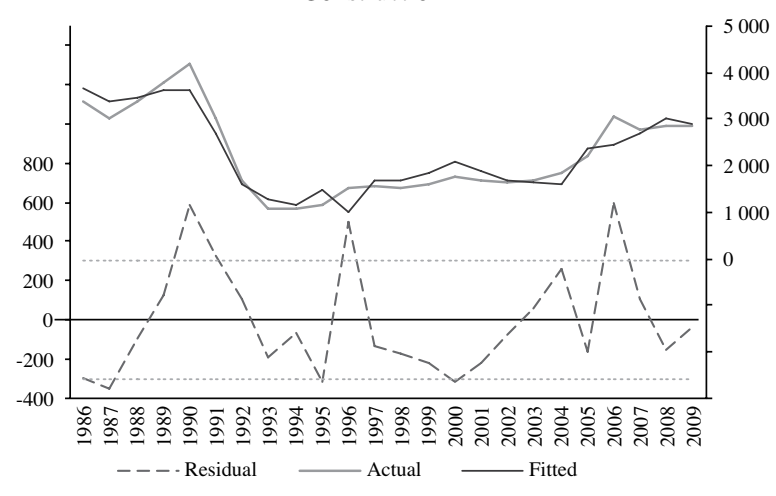

Transport and communications

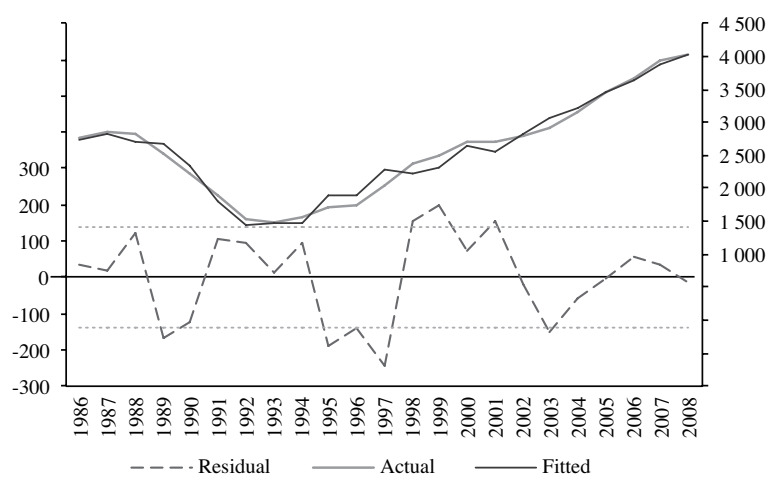

Basic industry

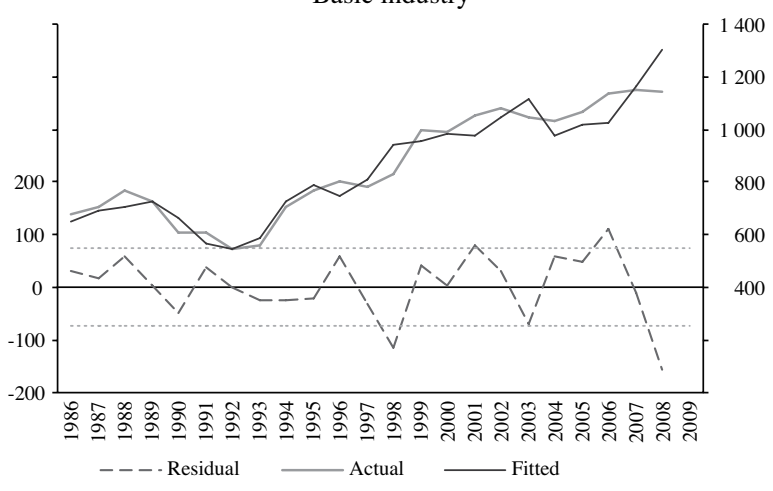

Manufacturing

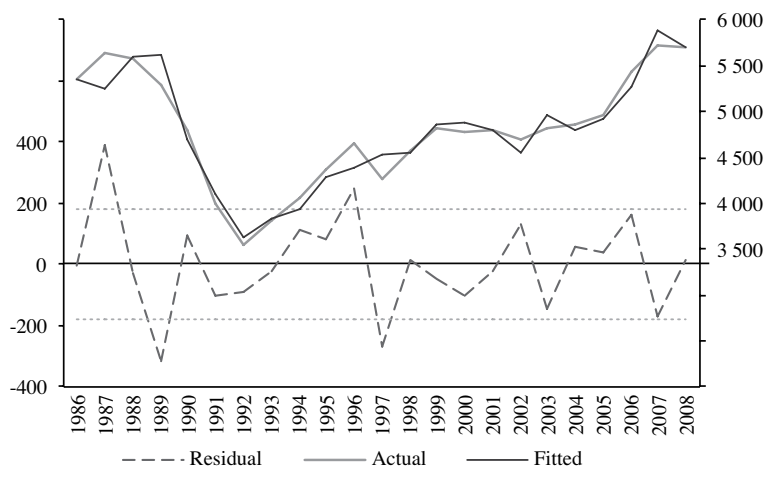

Tourism and commerce

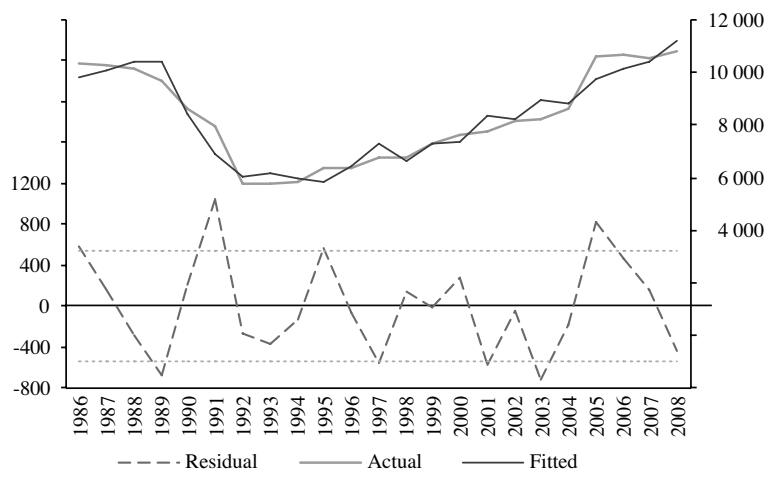

Source: prepared by the author.

a Trends in the estimate residuals, within the intervals shown in the figure, provide an indication of the model's ability to estimate and project GDP values for each of the areas of activity within the Cuban production sector in 1986-2009. 
Barro, R.J. (1997), Determinants of Economic Growth: a Cross Country Empirical Study, Cambridge, Massachusetts, MIT Press.

Barro, R.J. and J.W. Lee (2010), "A new data set of educational attainment in the world 1950-2010", NBER Working Paper, No. 15902, Cambridge, Massachusetts, National Bureau of Economic Research, April.

(1993), "International comparisons of educational attainment", NBER Working Paper, No. 4349, Cambridge, Massachusetts, National Bureau of Economic Research, April.

Benhabib, J. and M. Spiegel (1994), "The role of human capital in economic development: evidence from aggregate cross-country and regional U.S. data", Journal of Monetary Economics, vol. 34, No. 2, Amsterdam, Elsevier, October.

Caminos. Revista Cubana de Pensamiento Socioteológico (2010), No. 55-56, Havana, Editorial Centro Memorial Dr. Martin Luther King, Jr., January-June.

Caves, D.G. and L.R. Christensen (1980), "The relative efficiency of public and private firms in a competitive environment: the case of Canadian railroads", Journal of Political Economy, vol. 88, No. 5, Chicago, The University of Chicago Press, April.

Cribeiro, Y. and L. Triana (2005), "Las elasticidades en el comercio exterior cubano: Dinámica de corto y largo plazo", thesis, Havana, Faculty of Economics, University of Havana.

Cuba Foreign Trade (various issues), Havana, Chamber of Commerce of the Republic of Cuba.

Cuba: Inversiones y Negocios (various issues), Havana, Consultores Asociados S.A. (CONAS).

Diewert, W.E. (1971), "An application of the shephard duality theorem: a generalized Leontief production function", Journal of Political Economy, vol. 79, No. 3, Chicago, The University of Chicago Press, May-June.

Doimeadios, Y. (2007), "El crecimiento económico en Cuba: Un análisis desde la productividad total de los factores", thesis, Havana, Editorial Universitaria de la Universidad de la Habana.

ECLAC (Economic Commission for Latin America and the Caribbean) (2000), La economía cubana. Reformas estructurales y desempeño en los noventa, Mexico City, ECLAC/Fondo de Cultura Económica.

Freudenberg, M. (2003), "Composite indicators of country performance. A critical assessment", OECD Science, Technology and Industry Working Papers, No. 16, Paris, Organisation for Economic Cooperation and Development (OECD).

Fugarolas, A.U., D. Matesans and I. Mañalich (2008), "Empirical evidence of the balance of payment constrained growth in Cuba. The effects of commercial regimes since 1960", MPRA Paper, No. 6993, Munich, University Library of Munich, February.

González, A. (1995), "Modelos económicos socialistas: Escenarios para Cuba en los años noventa", Cuba: Investigación Económica, No. 3, Havana, July-October.

González, A. and others (1989), "Utilización de las funciones de producción macroeconómicas para el análisis de la eficiencia factorial", Havana, National Economic Research Institute.

Greene, W.H. (1997), Econometric Analysis, New Jersey, Prentice Hall. Harrod, R.F. (1939), "An essay in dynamic theory", The Economic Journal, vol. 49, No. 193, Wiley.
Jam, A. (2006), "Sobre la medición de los servicios sociales en el PIB de Cuba", paper prepared for Centro de Estudios de la Economía Cubana (CEEC), Havana, February, unpublished.

Kaldor, N. (1975), "Economic Growth and the Verdoorn Law-A Comment on Mr. Rowthorn's Article", The Economic Journal, vol. 85, No. 340, Royal Economic Society.

(1977), "Capitalism and industrial development: some lessons from Britain's experience", Cambridge Journal of Economics, vol. 1, No. 2, Oxford Journals.

Lucas, R. (1988), "On the mechanics of economic development", Journal of Monetary Economics, vol. 22, No. 1, Amsterdam, Elsevier.

Marquetti, H. (2006), "La reestructuración del sistema empresarial en Cuba: Tendencias principales", Reflexiones sobre economía cubana, Havana, Instituto Cubano del Libro.

Mendoza, Y. (2003), ¿¿Ha sido importante el capital humano en el crecimiento económico de Cuba?", Havana, National Economic Research Institute.

Mendoza, Y. and L. Robert (2000), "El crecimiento económico y las restricciones en el sector externo. Una aplicación al caso cubano", Havana, National Economic Research Institute, unpublished.

Nova, A. (2002), La UBPC y el cooperativismo en la agricultura cubana, Havana, Centro de Estudios de la Economía Cubana.

ONE (Oficina Nacional de Estadísticas) (various years), Anuario estadístico de Cuba, Havana. (1989), Anuario estadístico de Cuba, Havana.

Pérez, O.E. (2010), Estrategia económica: Medio siglo de socialismo en cincuenta años de la economía cubana, Havana, Editorial de Ciencias Sociales.

(2008), "La inversión extranjera directa en Cuba: Vientos a su favor?", Boletín Cuatrimestral del CEEC, Havana, Centro de Estudios de la Economía Cubana (CEEC), August.

(2006), "La inversión extranjera directa en el desarrollo económico. La experiencia cubana”, Reflexiones sobre economía cubana, Havana, Instituto Cubano del Libro.

Pérez-Izquierdo, V. and others (2003), "Los trabajadores por cuenta propia en Cuba", Havana, National Economic Research Institute.

Rebelo, S.T. (1991), "Long-run policy analysis and long-run growth", Journal of Political Economy, vol. 99, No. 3, Chicago, The University of Chicago Press.

Romer, P.M. (1986), "Increasing returns and long-run growth", Journal of Political Economy, vol. 94, No. 5.

Thirlwall, A. (1979), "The balance of payments constraint as an explanation of international growth rate differences", Banca Nazionale del Lavoro Quarterly Review, vol. 32, No. 128, Rome, Banca Nazionale del Lavoro.

Torres, R. (2007), "Cambio estructural y crecimiento económico en Cuba: Un enfoque a partir del uso de los factores productivos", Boletín trimestral del CEEC, Havana, Centro de Estudios de la Economía Cubana (CEEC).

Vidal, P. and A. Fundora (2008), "Trade-growth relationship in Cuba: estimation using the Kalman filter", CEPAL Review, No. 94 (LC/G.2357-P), Santiago, Chile, April. 